\author{
Janusz Mariański \\ Katolicki Uniwersytet Lubelski Jana Pawła II
}

\title{
ŚWIADOMOŚĆ MORALNA POLSKICH MATURZYSTÓW W LATACH 1994-2009
}

W zróżnicowanym społecznie i kulturowo społeczeństwie, w pluralistycznym i niepewnym świecie, miejsce młodego pokolenia jest szczególne. $Z$ badań socjologicznych wyłania się raczej pesymistyczny obraz młodej generacji, którą oskarża się o zainteresowanie przede wszystkim własnym ,ja”, o hedonizm i pragmatyzm, o orientację konsumpcjonistyczną, o brak zainteresowań politycznych, a nawet o skłonność do przemocy. Koncentracja na sobie prowadzi do kształtowania się postaw egoistycznych (tzw. egotycy). Z drugiej strony podkreśla się otwartość młodzieży na to co nowe, zdolność do reagowania i działania we właściwym momencie, kiedy pojawiają się nowe szanse i możliwości, co jest typową cechą nowoczesnych społeczeństw pluralistycznych [Gärtner: 2003: 97].

Obraz młodzieży ,,między pragmatycznym idealizmem a ciasnym materializmem" jest kwestionowany przez wielu badaczy, którzy wskazują na znaczną gotowość ludzi młodych do angażowania się w sprawy społeczne. Podważają oni tezę, że jest to pokolenie bez wartości i norm i podkreślają, że wielu ludzi młodych potrafi w ,obiecujący” sposób łączyć dobro wspólne z własnym interesem jako rzeczywistości komplementarne. Nie jest to z pewnością pokolenie „przegrywających”, „straconych” czy biernych obserwatorów życia społecznego. Należy podkreślić, że badania socjologiczne nad kondycją społeczną, polityczną, kulturalną, moralną i religijną młodzieży nie są w pełni konkluzyjne.

Europejskie i globalne procesy przemian społeczno-kulturowych oddziałuja na społeczeństwo polskie, na uznawane wartości, style życia, wzory odczuwania i działania. Zwłaszcza po 1989 r., kiedy otwarły się granice kraju dla swobodnego przepływu idei, poglądów i wzorów zachowań, wpływy te wydają się narastać. Media telekomunikacyjne wdarły się do wszystkich społecznych i ekonomicznych obszarów życia i działania. To, co było odległe, staje się nagle bliskie, a nawet bardzo bliskie, poprzez dryfowanie w wirtualnej rzeczywistości. Poprzez Internet można kontaktować się z całym światem i cieszyć się jakby wol- 
nością nieskrępowanych wyborów. Te przemiany i transformacje stają się horyzontem - zwłaszcza dla młodych - doświadczeń dnia codziennego, moralnych i politycznych wyzwań i dylematów walki o bezpieczeństwo materialne, karierę zawodowa, więzi z własnym partnerem, zakładaniem rodziny, kształtowaniem się nadziei i lęków. Sfera prywatna nabiera wymiarów globalnych, a świat przeżywany - mimo chaosu - jest jednak jakoś uporządkowany i znośny, a przede wszystkim możliwy do zaakceptowania [Beck: 2006: 26].

O władzę definiowania tego co słuszne i niesłuszne, dobre i złe, przyzwoite i nieprzyzwoite, godziwe i niegodziwe, ubiega się wiele instancji społecznych, a nade wszystko każda jednostka. W procesach indywidualizacyjnych kształtuja się wybory własnej drogi życiowej, własne cele i aspiracje życiowe, wartości i normy, przede wszystkim poszukiwanie własnego miejsca i roli w ustawicznie zmieniającej się rzeczywistości. Biografia moralna młodego człowieka kształtuje się obecnie pod hasłem „zrób to sam” i jest konstruowana $\mathrm{z}$ wielu elementów takich jak wartości, normy, preferowany styl życia, wierzenia religijne i przekonania ideologiczne, które „otrzymuje się” z bardzo wielu źródeł [Szlendak: 2000: 316]. Jest ona poniekąd „produktem” jednostki, ale nabiera charakteru dynamicznego, procesualnego projektu nigdy nie dokończonego, o wymiarach jakby rozproszonych, pomieszanych czy synkretycznych.

Nie wolno jednak zapominać, że społeczeństwo polskie, jakkolwiek jest poddane oddziaływaniom tych ogólnocywilizacyjnych i kulturowych trendów, zachowuje swoją specyfikę kulturową, religijną i być może - moralną, nawet jeżeli w wielu dziedzinach życia politycznego, społecznego i gospodarczego wykazuje tendencje imitacyjne (naśladowcze) w odniesieniu do społeczeństw zachodnich. Część młodzieży, zwłaszcza ta będąca pod wpływem kultury zachodniej, neguje obowiązujące wartości i normy składające się na tradycyjny etos społeczeństwa polskiego. $\mathrm{Z}$ drugiej strony jest liczna kategoria ludzi młodych, którzy pozostają wierni tradycyjnym wartościom i normom moralnym, a sama moralność stanowi dla nich istotne odniesienie [Świda-Ziemba: 2000: 164].

W rzeczywistości społecznej nie istnieje jedna moralność, lecz różne jej postaci (polimorficzna moralność). Nie może być zresztą inaczej, bowiem w ponowoczesnej rzeczywistości społeczno-kulturowej jest wiele niejednoznaczności, ambiwalencji, efemeryczności, fragmentaryzacji, fluktuacji itp., związanych $\mathrm{z}$ radykalnymi zmianami i przekształceniami (płaszczyzna społeczna), a po drugie, młodzież znajduje się w fazie wchodzenia w dorosłość, co wiąże się z kwestionowaniem dotychczasowej tożsamości charakterystycznej dla okresu dzieciństwa i poszukiwaniem nowych źródeł sensu własnej egzystencji (płaszczyzna indywidualna). Niepewność i nieprzewidywalność sytuacji społecznych, charakteryzujące współczesne społeczeństwa, stanowi trudne i wymagające środowisko dla funkcjonowania młodego pokolenia. 
Zmiany w postawach i zachowaniach moralnych młodzieży oscylują między absolutyzmem i rygoryzmem moralnym (niekiedy nawet fundamentalizmem), który w Polsce jest związany głównie z oddziaływaniem Kościoła katolickiego, a tendencjami do utylitaryzmu, permisywizmu i relatywizmu moralnego, w których szczególnie akcentuje się prawa jednostki do autonomii, niezależności, dążenia do realizacji własnych interesów i własnego szczęścia. Osłabienie pierwszej tendencji jest odczytane przez zwolenników stałego ładu moralnego jako zagrożenie dla kondycji moralnej społeczeństwa, wzmocnienie tej drugiej jest interpretowane przez innych jako autonomiczne kreowanie wartości i norm moralnych, a ich niezależny wybór jest podstawą i wyrazem wolności oraz podmiotowości człowieka. Przemiany współczesne moralności w warunkach modernizacji społecznej prowadzą do nasilania się trendu relatywizacji wartości i norm moralnych, w tym także kryteriów odróżniania dobra i zła moralnego. Z pewnością nasilają się procesy permisywizmu wobec postaw i zachowań, które były uznawane za niedopuszczalne w warunkach tradycyjnych społeczeństw i dominacji autorytetów religijnych.

W niniejszym opracowaniu, które obejmuje tylko część zgromadzonych materiałów empirycznych dotyczących moralności maturzystów, zwrócimy uwagę tylko na wybrane kwestie, prezentowane w kilku punktach, bez próby przedstawienia jakiegokolwiek ,całościowego obrazu”. Na podstawie zebranych i przeanalizowanych wyników badań empirycznych w niniejszym artykule socjologicznym ukazujemy moralność młodzieży polskiej z końca pierwszej dekady XXI w. (głównie wartości, normy i oceny moralne) oraz jej przemiany. Staramy się, by sformułowane tezy i hipotezy były mocno osadzone w rozległej dokumentacji empirycznej i nie dotyczyły wyłącznie bilansu negatywów i strat. Unikamy wkraczania $w$ sferę nieuzasadnionych hipotez i niemożliwych do sprawdzenia wyobrażeń, intuicji i przypuszczeń.

Dla uchwycenia przemian w moralności młodzieży polskiej w roku szkolnym 2008/2009 zostały przeprowadzone w pięciu miastach badania socjologiczne (Dęblin, Gdańsk, Kraśnik, Puławy, Szprotawa), w tych samych szkołach i klasach co i w roku szkolnym 1994/1995. Po 15 latach warto na nowo diagnozować młodzież maturalna, ale także postawić pytania, co się w tym czasie zmieniło i w jakim kierunku dokonują się zmiany w moralności młodzieży. Badania powtarzane stwarzają szansę uchwycenia dynamiki zjawisk i zachodzących procesów. Wnioski z jednego pomiaru zjawisk moralnych nie mogłyby określić zmian w moralności, tym bardziej upoważniać do wniosku o malejącym czy wzrastającym wpływie zasad moralnych na postępowanie ludzi, o malejącym czy wzrastającym wpływie religii na życie indywidualne i społeczne. Badanie takie będące swoistą fotografią hic et nunc mogłoby mieć charakter wyłącznie eksploracyjny, z kolei badania powtarzane pozwalają ustalić to, co zmieniło się w orientacjach moralnych maturzystów w latach 1994/2009. 
W sumie spośród 1074 osób wytypowanych do badań, przeprowadzonych przez magistrantów z Katedry Socjologii Moralności KUL, przebadano 992 maturzystów, co stanowi 92,4\% założonej próby badawczej. Część maturzystów wyraźnie odmówiła udzielenia odpowiedzi na ankietę $(2,6 \%)$, część była nieuchwytna, mimo ponawianych prób dotarcia do nich $(4,1 \%)$, kilkanaście ankiet wyłączono z dalszych analiz statystycznych ze względu na znaczny brak odpowiedzi lub niepoważne odpowiedzi $(0,9 \%)$. Ze względu na sposób doboru próby badawczej młodzież maturalna którą poddano badaniom nie może być uznana za reprezentację rocznika 2008/2009, co najwyżej za pewne przybliżenie do ,średniej krajowej”. Uzyskanie wyników empirycznych z różnych środowisk miejskich i ich porównywanie może częściowo upoważniać do formułowania uogólnień o dość szerokim zasięgu. Porównanie zaś danych z 1993/1994 i 2008/2009 daje podstawy do wniosków na temat dynamiki moralności w świadomości maturzystów.

\section{Dekalog jako podstawa moralności}

Przykazania Dekalogu stanowią drogowskaz życiowy, należą one - według religii - do Przymierza pomiędzy Bogiem i ludzkością. Są wartością religijną i moralną. Przykazania wyznaczaja zasadnicze zręby postępowania, decyduja o wartości moralnej ludzkich czynów, pozostaja w organicznym zwiazku z powotaniem człowieka do życia wiecznego, z urzeczywistnianiem się królestwa Bożego w ludziach i pośród ludzi. W stowo Bożego Objawienia wpisany jest wyraźny kodeks moralności, którego punktem kluczowym pozostaja synajskie tablice Dekalogu - natomiast punkt szczytowy znajduje się $w$ Ewangelii: $w$ Kazaniu na górze $i w$ przykazaniu mitości. Mają one zasadnicze znaczenie dla rozwoju świadomości moralnej młodych, dla kształtowania projektu życia. Papież Jan Paweł II dodaje: Trzeba, ażeby sam podstawowy zapis zasad moralności nie ulegt deformacji ze strony jakiegokolwiek relatywizmu czy też utylitaryzmu [List Apostolski Jana Pawła II do młodych całego świata z okazji Międzynarodowego Roku Młodzieży z 31 marca 1985 r.] $]^{1}$.

Dekalog jest zwięzłą syntezą oczywistych zasad wszelkich moralności. W dekalogu zawarty jest zestaw podstawowych nakazów i zakazów, na podstawie których kształtowała się ludzka osobowość, wspótżycie rodzinne $i$ więzi tqczqce małe grupy. Wartości judeochrześcijańskie stanowity fundament prawodawstwa regulujacego porzadek większości europejskich krajów $i$ zasady prawodawstwa międzynarodowego. Wartości te stanowity niezbędne spoiwo integrujace ludzkie osobowości i grupy społeczne [Pawełczyńska: 2004: 91]. Dekalog jest zbiorem praw, które regulują i zapewniają spokój, porządek i szczęście wszystkim narodom.

\footnotetext{
1 „L' Osservatore Romano” 1985, nr 1, s. 6.
} 
Pomimo niewątpliwych negatywnych zmian w świadomości moralnej Polaków po 1989 r., można w dalszym ciągu twierdzić, że w ustosunkowaniu się do przykazań Dekalogu pozostają oni pod silnym wpływem tradycji judeochrześcijańskich. Trzy pierwsze przykazania (,religijne”) mają nieco niższą akceptację niż pozostałe (,moralne”). Można stąd wnosić, że młodzież polska ma większe trudności z uchwyceniem teologicznego sensu przykazań określających obowiązki wobec Boga niż obowiązki wobec bliźnich. Jeżeli uwzględnić łączny wskaźnik odpowiedzi „zdecydowanie wiążące” i „raczej wiążące”, wówczas wskaźnik pozytywnej oceny przykazań Boskich - z wyjątkiem środowisk wielkomiejskich - przekroczy granicę 80\% [Mariański: 2009: 17-19].

Badanym maturzystom w roku szkolnym 2008/2009 z pięciu miast różnej wielkości postawiono pytanie odnoszące się do Dekalogu z prośbą o określenie, które z tych przykazań są dla nich osobiście wiążące. Respondenci oceniali każde $\mathrm{z}$ tych przykazań $\mathrm{w}$ jeden $\mathrm{z}$ czterech zasygnalizowanych sposobów: ma zastosowanie całkowite, ma zastosowanie częściowe, nie ma żadnego zastosowania, nie umiem powiedzieć. Uzyskane wyniki empiryczne prezentuje tab. 1 zawierająca dane dotyczące całej zbiorowości maturzystów z 2009 r. i 1994 r.

Tabela 1

Postawy maturzystów wobec Dekalogu (dane w \%)

\begin{tabular}{|c|c|c|c|c|c|c|c|c|c|c|c|c|}
\hline \multirow{2}{*}{$\begin{array}{c}\text { Przykazania } \\
\text { Dekalogu }\end{array}$} & \multicolumn{2}{|c|}{$\begin{array}{c}\text { Zastosowani } \\
\text { całkowite }\end{array}$} & \multicolumn{2}{|c|}{$\begin{array}{l}\text { Zastosowanie } \\
\text { częściowe }\end{array}$} & \multicolumn{2}{|c|}{$\begin{array}{c}\text { Nie ma } \\
\text { zastosowania }\end{array}$} & \multicolumn{2}{|c|}{$\begin{array}{c}\text { Trudno } \\
\text { powiedzieć }\end{array}$} & \multicolumn{2}{|c|}{$\begin{array}{c}\text { Brak } \\
\text { danych }\end{array}$} & \multicolumn{2}{|c|}{ Razem } \\
\hline & I & II & $\mathrm{I}$ & II & $T_{1}$ & II & I & II & I & II & I & II \\
\hline $\begin{array}{l}\text { rzykazanie } \\
\text { I }\end{array}$ & 64,8 & & & 4,8 & 9,0 & 8,3 & 6,9 & 0,3 & 4,0 & 0,0 & & 100,0 \\
\hline $\begin{array}{c}\text { Przykazanie } \\
\text { II }\end{array}$ & & & & & 1,3 & & 4,1 & 8 & 4,0 & 8 & & 100,0 \\
\hline $\begin{array}{c}\text { Przykazanie } \\
\text { III }\end{array}$ & & & & & 1,2 & & 1,7 & 4 & $J, J$ & 0,2 & 0,0 & $\pi, 0$ \\
\hline zanie & &, 5 & 28,4 & 3,6 & 1,4 & & 1,3 & 4,5 & 3,7 & 9,5 & 00,0 & 100,0 \\
\hline zanie &, 4 & 6,8 & 8,6 &, 8 & 2,5 & 3,3 & 2,1 & 4,2 & 3,5 & 9,8 & 00,0 & 100,0 \\
\hline $\begin{array}{c}\text { Przykazanie } \\
\text { VI }\end{array}$ & & , & 6 &, 7 & 12,7 & 9,5 & 6,9 & 6,5 &, 9 & 0,4 & 00,0 & 100,0 \\
\hline $\begin{array}{c}\text { Przykazanie } \\
\text { VII }\end{array}$ & & & & & 5,4 & & 1,3 & 4,0 & 3,8 & 0,5 & 00,0 & 100,0 \\
\hline $\begin{array}{c}\text { Przykazanie } \\
\text { VIII }\end{array}$ & & ,6 &, 2 & , & 7,0 & &, 3 & 6,3 & ,9 & 0,8 & 00,0 & 100,0 \\
\hline $\begin{array}{c}\text { Przykazanie } \\
\text { IX }\end{array}$ & 56,5 & 2,7 & 22,7 & 20,5 & 9,9 & 1,2 & 7,0 & 8,8 & 3,8 & 10,9 & 100,0 & 100,0 \\
\hline $\begin{array}{c}\text { Przykazanie } \\
\text { X } \\
\end{array}$ & 45,1 & 39,8 & 38,0 & 34,2 & 7,7 & 8,7 & 5,1 & 7,3 & 4,1 & 10,1 & 100,0 & 100,0 \\
\hline
\end{tabular}


Według kategorii odpowiedzi „ma zastosowanie całkowite” najbardziej akceptowane są cztery przykazania ,,moralne” (V, VII, IV i IX) oraz jedno przykazanie „religijne” (I), najmniej zaś dwa przykazania „religijne” (II i III) oraz dwa przykazania „moralne” (VIII i X). Aprobata poszczególnych przykazań wahała się od $16,6 \%$ do $76,8 \%$ (różnica wskaźników - 60,2\%). Trzy pierwsze przykazania są mniej akceptowane niż siedem przykazań „moralnych” (35,6\% wobec $55,0 \%)$. Można stąd wnosić, że młodzież maturalna ma większe trudności $\mathrm{z}$ uchwyceniem teologicznego sensu przykazań określających obowiązi wobec Boga niż z dostrzeżeniem ich waloru moralnego (obowiązki wobec bliźnich). Jeżeli uwzględnić łączny wskaźnik odpowiedzi „ma zastosowanie całkowite” i „ma zastosowanie częściowe”, wówczas wskaźnik pozytywnej oceny przykazań Bożych waha się od 59,0\% do 84,1\% (wskaźnik przeciętny - 74,7\%). Tylko w odniesieniu do trzech przykazań (IV, V i VII) przekracza granicę oczywistości kulturowej, tj. $80 \%$ aprobaty.

Przeciętny wskaźnik pełnej aprobaty kształtował się w całej badanej zbiorowości maturzystów na poziomie $49,1 \%$, aprobaty częściowej $-25,6 \%$, braku aprobaty $-8,5 \%$, niezdecydowania (,,nie umiem powiedzieć”) $-6,5 \%$ i braku odpowiedzi - 10,3\%; w Szprotawie odpowiednio: 47,4\%, 22,9\%, 10,9\%, 3,9\%, 14,9\%; w Puławach - 47,5\%, 24,4\%, 6,8\%, 6,2\%, 15,1\%; w Kraśniku - 52,6\%, 25,4\%, 5,3\%, 9,3\%, 7,4\%; w Dęblinie - 52,2\%, 28,6\%, 10,3\%, 7,6\%, 1,3\%; w Gdańsku - 48,4\%, 29,8\%, 11,5\%, 5,8\%, 4,5\%. Wskaźnik przeciętnej aprobaty nie przekroczył $50 \%$ i był najniższy w Puławach, Gdańsku i Szprotawie. Wskaźniki tych, którzy kwestionują sens Dekalogu lub wątpią w jego poszczególne przykazania, albo nie są w stanie wypowiedzieć oceny pozytywnej albo negatywnej, obejmuje około czwartą część badanych młodych Polaków.

W latach 1994-2009 zaznaczyły się pewne zmiany w aprobacie przykazań Dekalogu. Straciły na znaczeniu według oceny „ma zastosowanie całkowite” następujące przykazania: przykazanie I (różnica 8,1\%), przykazanie (różnica $2,1 \%$ ), przykazanie III (różnica 9,2\%), przykazanie IV (różnica 4,7\%), przykazanie V (różnica 6,6\%), przykazanie VII (różnica 1,4\%), przykazanie VIII (różnica 3,0\%), przykazanie IX (różnica 3,8\%), przykazanie X (różnica 5,3\%) i zyskało nieco na znaczeniu przykazanie VI (różnica 3,0\%). Przykazania ,religijne” straciły nieco na znaczeniu (spadek aprobaty o 6,5\%), w nieco mniejszym stopniu zmniejszyła się aprobata przykazań „moralnych” (różnica 5,5\%). W okresie 15 lat dokonały się wyraźne zmiany, nie można więc mówić o stabilizacji postaw młodzieży maturalnej wobec Dekalogu. Potwierdza to również wskaźnik zbiorczy. W 1994 r. 53,3\% badanych zostało zakwalifikowanych do kategorii uznających, że przykazania Dekalogu mają w ich życiu całkowite zastosowanie, $30,1 \%$ - zastosowanie częściowe, $8,8 \%$ - nie mają zastosowanie, $4,0 \%$ - trudno powiedzieć i 3,8\% - brak odpowiedzi. Biorąc pod uwagę wskaźniki aprobaty pełnej i częściowej można powiedzieć, że w latach 1994-2009 wskaźnik ten zmniejszył się o 8,7\% (od 83,4\% do 74,7\%), w Szprotawie o 15,5\%, w Puła- 
wach o 13,4\%, w Kraśniku o 6,0\% oraz wzrósł w Dęblinie (o 2,8\%) i w Gdańsku (o 2,8\%).

Z dotychczasowych badań socjologicznych wynika, że Polacy odnoszą negatywne zmiany w aprobacie przykazań Dekalogu nie tyle do siebie, ile raczej do innych ludzi. Porównanie mocy wiążącej przykazań Bożych we własnym życiu i w życiu tzw. większości Polaków wskazuje, że oceny te są wyraźnie rozbieżne. O ile większość młodych i dorosłych Polaków uznaje jeszcze za wiążące przykazania Dekalogu w swoim życiu (całkowicie lub częściowo), to równocześnie deklaruje, że tzw. większość Polaków nie uznaje ich za wiążące, prawdopodobnie jako niedostosowane do czasów współczesnych, a nawet uznaje je za przestarzałe, w każdym razie dość powszechnie nierespektowane. Badanym maturzystom postawiono także pytanie o to, czy - w ich przekonaniu przykazania Dekalogu mają dzisiaj zastosowanie całkowite, częściowe lub żadne dla większości ludzi w naszym kraju. Uzyskane dane empiryczne są zawarte w tab. 2 .

Tabela 2

Stosunek większości Polaków do norm Dekalogu w opinii maturzystów (dane w \%)

\begin{tabular}{|c|c|c|c|c|c|c|c|c|c|c|c|c|}
\hline \multirow{2}{*}{$\begin{array}{c}\text { Przykazania } \\
\text { Dekalogu }\end{array}$} & $\begin{array}{c}\text { Zastosowanie } \\
\text { całkowite }\end{array}$ & $\begin{array}{c}\text { Zastosowanie } \\
\text { częściowe }\end{array}$ & $\begin{array}{c}\text { Nie ma } \\
\text { zastosowania }\end{array}$ & \multicolumn{2}{c|}{$\begin{array}{c}\text { Trudno } \\
\text { powiedzié }\end{array}$} & \multicolumn{2}{c|}{$\begin{array}{c}\text { Brak } \\
\text { danych }\end{array}$} & Razem \\
\hline $\begin{array}{c}\text { Przykazanie } \\
\text { I }\end{array}$ & 16,1 & 20,4 & 46,4 & 42,2 & 6,5 & 8,5 & 26,4 & 18,3 & 4,6 & 10,6 & 100,0 & 100,0 \\
\hline $\begin{array}{c}\text { Przykazanie } \\
\text { II }\end{array}$ & 6,0 & 8,3 & 39,9 & 36,8 & 28,1 & 28,2 & 21,4 & 16,5 & 4,6 & 10,2 & 100,0 & 100,0 \\
\hline $\begin{array}{c}\text { Przykazanie } \\
\text { III }\end{array}$ & 11,6 & 12,0 & 59,7 & 51,8 & 8,2 & 11,5 & 15,9 & 14,4 & 4,5 & 10,3 & 100,0 & 100,0 \\
\hline $\begin{array}{c}\text { Przykazanie } \\
\text { IV }\end{array}$ & 17,6 & 20,3 & 50,0 & 48,2 & 4,3 & 4,3 & 23,1 & 16,3 & 4,9 & 10,9 & 100,0 & 100,0 \\
\hline $\begin{array}{c}\text { Przykazanie } \\
\text { V }\end{array}$ & 25,0 & 29,9 & 44,6 & 41,7 & 7,6 & 6,7 & 18,3 & 11,2 & 4,5 & 10,5 & 100,0 & 100,0 \\
\hline $\begin{array}{c}\text { Przykazanie } \\
\text { VI }\end{array}$ & 7,2 & 11,4 & 44,2 & 44,5 & 23,0 & 19,7 & 21,1 & 14,1 & 4,5 & 10,4 & 100,0 & 100,0 \\
\hline $\begin{array}{c}\text { Przykazanie } \\
\text { VII }\end{array}$ & 9,5 & 12,7 & 48,3 & 48,3 & 20,2 & 15,5 & 17,3 & 13,1 & 4,6 & 10,4 & 100,0 & 100,0 \\
\hline $\begin{array}{c}\text { Przykazanie } \\
\text { VIII }\end{array}$ & 5,6 & 6,3 & 41,1 & 43,2 & 28,0 & 25,6 & 20,3 & 4,5 & 10,4 & 5,0 & 100,0 & 100,0 \\
\hline $\begin{array}{c}\text { Przykazanie } \\
\text { IX }\end{array}$ & 7,0 & 9,1 & 44,6 & 46,4 & 17,1 & 15,9 & 26,1 & 8,3 & 5,2 & 10,3 & 100,0 & 100,0 \\
\hline $\begin{array}{c}\text { Przykazanie } \\
\text { X }\end{array}$ & 7,4 & 8,3 & 40,4 & 43,2 & 22,3 & 19,2 & 25,3 & 18,1 & 4,6 & 1,2 & 100,0 & 100,0 \\
\hline
\end{tabular}


Maturzyści bardziej krytycznie oceniają wierność teoretyczną i praktyczną przykazaniom Dekalogu w życiu większości Polaków niż u siebie. Według kategorii odpowiedzi „ma zastosowanie całkowite” najbardziej akceptowane przez większość Polaków są dwa przykazania „moralne” (IV i V) oraz jedno przykazanie „religijne” (I). Pozostałe przykazania są aprobowane przez nieco częściej lub nieco rzadziej niż przez co dziesiątego Polaka (w ocenie maturzystów). Aprobata pełna poszczególnych przykazań waha się od 6,3\% do 29,9\% (różnica wskaźników - 23,6\%). Trzy pierwsze przykazania, czyli „religijne”, są równie często aprobowane przez większość Polaków jak i przykazania „moralne” $(13,6 \%$ i 14,0\%). W ocenie własnej maturzyści znacznie częściej przypisywali sobie aprobatę przykazań „moralnych” niż „religijnych”. Jeżeli uwzględnić łącznie wskaźnik odpowiedzi (,ma zastosowanie całkowite” i „ma zastosowanie częściowe"), wówczas wskaźnik pozytywnej oceny przykazań Dekalogu waha się od $45,1 \%$ do 71,6\% (przeciętny wskaźnik 58,5\%). W odniesieniu do wszystkich przykazań Bożych wskaźnik przypisywanej Polakom aprobaty Dekalogu spada - z wyjątkiem przykazania IV, V i VII - poniżej granicy $60 \%$.

Przeciętny wskaźnik pełnej aprobaty Dekalogu kształtował się w społeczeństwie polskim - według zbiorczej oceny maturzystów - na poziomie 13,9\%, aprobaty częściowej - 44,6\%, braku aprobaty - 15,4\%, niezdecydowania 15,5\% i braku odpowiedzi - 10,5\%; w Szprotawie odpowiednio: 15,5\%, 42,8\%, $15,3 \%, 12,4 \%, 14,0 \%$; w Puławach - 12,3\%, 44,6\%, 13,7\%, 15,3\%, 14,1\%; w Kraśniku - 14,9\%, 43,0\%, 12,8\%, 20,2\%, 9,1\%; w Dęblinie - 11,9\%, 50,8\%, $18,1 \%, 14,6 \%, 4,6 \%$; w Gdańsku - 12,9\%, 47,7\%, 21,0\%, 13,3\%, 5,1\%. Wskaźnik przeciętnej aprobaty pełnej nie przekroczył $14,0 \%$ i kształtował się na zbliżonym poziomie we wszystkich pięciu miastach, podobnie łączny wskaźnik aprobaty pełnej i częściowej wahał się w poszczególnych miastach od 56,9\% do $62,7 \%$. Opinie o stosunku większości Polaków do Dekalogu były podobne wśród maturzystów w pięciu miastach i sytuowały się na znacznie niższym poziomie niż analogiczne opinie odnoszące się do samych respondentów.

W latach 1994-2009 nie nastapiły bardziej znaczące zmiany w opiniach maturzystów, a przesunięcia $\mathrm{w}$ aprobacie poszczególnych przykazań mieściły się w granicach 5\%. Według wskaźnika zbiorczego aprobata pełna kształtowała się w 1994 r. na poziomie $11,3 \%$, aprobata częściowa - 45,9\%, brak aprobaty $16,6 \%$, niezdecydowanie $-21,5 \%$ i brak odpowiedzi $-4,7 \%$. Łączny wskaźnik pełnej i częściowej aprobaty wynosił 57,2\% i był niższy od tego z 2009 r. o 1,3\%. Można więc mówić o ustabilizowaniu się poglądów i opinii maturzystów polskich o swoich rodakach w kwestii respektowania Dekalogu, ale nie sa to opinie i poglądy do końca pozytywne. Podobnie jak przed 15 laty, tak i obecnie, ponad trzecia część ankietowanych maturzystów przypisuje Polakom raczej liberalny stosunek do norm Dekalogu.

Być może wypowiadane oceny i opinie tylko częściowo odzwierciedlaja moralność społeczeństwa polskiego. W opinii ponad trzeciej części młodzieży 
maturalnej przykazania Dekalogu straciły na ważności w życiu większości Polaków i w mniejszym stopniu do nich samych. W ocenie uzyskanych wyników empirycznych musimy jednak pamiętać o występowaniu psychospołecznego mechanizmu polegającego na większym krytycyzmie wobec otoczenia niż wobec siebie, o bardziej tolerancyjnym, a nawet liberalnym spojrzeniu na własną osobę. Dekalog jako podstawowa kodyfikacja norm moralnych przyjęta w kulturze judeochrześcijańskiej jest jeszcze w szerokim zakresie akceptowany w środowiskach młodzieży wsi, małych i średnich miast, w mniejszym stopniu w środowiskach wielkomiejskich, a jego fundamentalne zasady nie straciły jeszcze nośności społecznej.

Wskaźnik pełnej aprobaty przykazań Boskich obejmuje jeszcze około połowę badanych, co przy nieznacznym odrzuceniu tych przykazań pozwala wyciagnać wniosek, że pokolenie współczesnej młodzieży polskiej pozostaje jeszcze pod silnym wpływem tradycji religijnych. W odniesieniu do wartości i norm o charakterze ogólnym mamy nie tyle do czynienia z jakąś negacją dobra moralnego, ile raczej $z$ chwiejną dezorientacją $\mathrm{i}$ ambiwalencją. Dla części młodych ludzi przykazania Dekalogu nie są normami absolutnymi, ich ważność jest prawdopodobnie dostrzegana tylko w niektórych okolicznościach i pomijana w innych sytuacjach (około 25\%). Aprobata przykazań przez młodzież jest niższa niż w całym społeczeństwie, ale różnice dotyczą nie tyle negacji przykazań, ile raczej stopnia ich akceptacji. W latach 1994-2009 wskaźnik pełnej lub częściowej aprobaty Dekalogu zmniejszył się o 8,7\%.

Dość jeszcze wysoka akceptacja przykazań Dekalogu nie oznacza, że w świadomości badanych Polaków nie dokonują się przemiany idące w kierunku sytuacyjnie uwarunkowanych imperatywów etycznych. Przejście od moralności obiektywnej do subiektywnej, od moralności nakazów i zakazów do moralności indywidualnych opcji, od moralności rygorystycznej do moralności wolnej od nadmiernych rygorów (permisywnej) może dokonywać się na poziomie bardziej konkretnych reguł i zasad życia moralnego, zwłaszcza dotyczących życia małżeńsko-rodzinnego. Relatywizacja moralności przejawia się z rozmaitym nasileniem na płaszczyźnie życia codziennego. Sam Dekalog przez większość maturzystów jest jeszcze akceptowany, ale dla pewnej części (mniejszości) staje się niewygodny, a jako zbiór przepisów zbyt rygorystycznych jest traktowany jako ograniczanie wolności człowieka.

\section{Wartości absolutne versus wartości relatywne}

W ponowoczesnym świecie ścierają się dwie przeciwstawne teorie: absolutyzm moralny i relatywizm. Według Andrzeja Szahaja absolutyzm - w sensie ogólnym - oznacza, że (...) określone przekonania, sqdy i wartości sq niezmienne oraz prawdziwe $w$ sensie prawdy absolutnej $i$ obowiqzuja niezależnie od 
punktu widzenia jednostek, interesów grup społecznych, kultury danej społeczności czy procesów historycznych. Sq one zatem stałe, bezwzględne, bezalternatywne, spójne, pewne i konieczne [Szahaj: 2008: 17]. W odniesieniu do sfery moralności oznacza to, że istnieją nakazy i przykazania mające charakter kategoryczny, tzn. nie nakazują czegoś pod jakimś warunkiem (warunkowo) lecz kategorycznie i bezwarunkowo. Są one bezwzględnie wiążące, wobec nich przeżywamy jakby wrażenie przymusu, czujemy, że nie wolno nam postapić inaczej niż chce nakaz. Moralność taka nie obiecuje żadnej nagrody za wykonanie obowiązku, co więcej, nie przestałaby obowiązywać, gdyby ich zachowanie miało pociągnąc za sobą karę [Bocheński: 1995: 38-39].

Według relatywizmu - zwłaszcza w formie skrajnej - wartości i normy moralne nie mają obiektywnych podstaw i są jedynie wyrazem subiektywnych, niekiedy arbitralnych wyborów jednostki. Różnice w upodobaniach, a nie obiektywna zasadność decyduje o dobru lub złu. Relatywizm prowadzi do dezorganizacji naturalnych więzi społecznych opartych na wartościach i normach moralnych oraz stwarza warunki do umocnienia się więzi interesów (zdezorganizowana moralność). Wspótczesne zło bardzo trudno oddzielić od dobra. Dawniej istniaty powszechnie przyjmowane jednoznaczne kryteria, które określaty dobro i zło. Obecnie nastapito zaktócenie jednoznaczności pojęć. Przyczynita się do tego obowiazujaca $w$ nauce teoria relatywizmu moralnego [Liberalny totalitaryzm: 2005: 30]. Według relatywizmu to samo zachowanie może być uznane za moralne w jednej sytuacji, za niemoralne - w drugiej. Tradycyjne wartości i normy podlegają w skali społecznej daleko idącej dezorganizacji, w skali indywidualnej - zakwestionowaniu, a nawet wyraźnemu odrzuceniu. Pomiędzy dwiema ujęciami krańcowymi (absolutyzm versus relatywizm) istnieje szereg form pośrednich, o większej lub słabszej sile relatywizmu i absolutyzmu (,twardy” i „miękki”). Relatywizm w znaczeniu wulgarnym oznacza pogląd, że wszystko jest względne, że wszystko jest tak samo dobre (nihilizm aksjologiczny).

W naszych rozważaniach termin ,,wartości absolutne” odnosi się do obiektywnego stanu rzeczy, niezależnie od tego, jak ludzie tę obiektywność oceniają. Dana wartość ma w sobie coś istotnego, niezależnie od osoby oceniającej. Wartości absolutne (obiektywne, uniwersalne) utrzymują swoją moc niezależnie od sytuacji życiowych, konkretnych uwarunkowań społecznych i historycznych, wskazują na pewien stały ład moralny w społeczeństwie. W warunkach gwałtownych i radykalnych przemian społeczno-kulturowych dochodzi niejednokrotnie do zakwestionowania obowiązujących wartości i norm o charakterze uniwersalnym, na rzecz wartości relatywnych. Wartości relatywne są uzależnione w swojej mocy normatywnej od aktualnych potrzeb, pragnień i dążeń jednostek i grup społecznych. Według relatywizmu (...) wartości moralne wyższe, takie jak dobro i prawda, nie sq stabilne, lecz zmieniaja swój sens - sq relatywizowane wobec pogladów lub wobec pozycji obserwatorów, a także $w$ zależności od ustrojów społecznych, w jakich obserwatorzy funkcjonuja. Przy 
takim założeniu nie jest możliwy żaden trwały $i$ uniwersalny system wartości, a tym samym nie ma żadnego punktu oparcia ani układu odniesienia [Pawełczyńska: 2004: 11].

W świetle dotychczasowych badań empirycznych można twierdzić, że świadomość moralna Polaków ulega procesom pluralizacji i relatywizacji. Odeszli oni już daleko od kategorycznych norm moralnych w kierunku sytuacyjnie uwarunkowanych imperatywów etycznych. Wyznawana przez nich etyka mieści się jakby pośrodku między legalizmem i sytuacjonizmem, często zaś ewoluuje w kierunku absolutnej niezależności od systemów etycznych, w tym także od religii, w której wolność jest absolutnym prawem jednostki, a sumienie czysto subiektywną i całkowicie autonomiczną instancją normotwórczą. Znaczna część Polaków, zwłaszcza młodych, nie chce kierować się kategorycznymi i obiektywnymi normami moralnymi, lecz raczej normami pozostawionymi własnemu wyborowi, albo kryteriami celowościowo-pragmatycznymi. Wydaje się to zapowiadać głęboki i szeroki zarazem kryzys podstawowych pojęć moralnych [Ziółkowski: 2006: 145]. Jest to coś więcej niż permisywizm moralny. Perfekcjonizm nakładający wysokie wymagania $\mathrm{w}$ dziedzinie postaw i zachowań ocenianych w kategoriach moralnych, traci na znaczeniu [Kiciński: 2008: 381], umacnia się kultura o osłabionej normatywności, a niekiedy nawet anormatywności (według rzymskiej zasady et $-e t ; i-i$ ). Dalecy jesteśmy od reguł o charakterze normatywnym, których nie da się wyprowadzić z warunków społecznych i kontekstów historycznych, bowiem mówią one o tym, co ludzie czynić powinni, co jest dobre a co złe.

Na tle wyników badań socjologicznych i sondaży opinii publicznej stawiamy pytanie dotyczące poglądów maturzystów polskich na temat roli, jaką powinny odgrywać w życiu człowieka wartości i normy moralne. Mogą być one uznawane jako obowiązujące zawsze i we wszystkich okolicznościach (uniwersalizm), bądź jako względne, partykularne, uzależnione od konkretnych sytuacji i okoliczności (relatywizm). Trzeba także pamiętać, że młodzież wchodząc w ustrukturalizowany świat ludzi dorosłych, musi wypracowywać własną orientację aksjologiczną, budować swój osobisty system wartości i indywidualną strategię życia [Styk: 2008: 73]. Dla ustalenia, czy młodzież maturalna skłania się ku etyce uniwersalistycznej (rygorystycznej, absolutnej) czy relatywistycznej (sytuacyjnej), wszystkim respondentom postawiono następujące pytanie: „Przedstawiamy Tobie dwa twierdzenia, które ludzie czasami wypowiadają na temat dobra i zła. Które jest bliższe Tobie?

A - Istnieją całkowicie jasne kryteria określające, co jest dobre, a co złe. Mają one zastosowanie do każdego, niezależnie od okoliczności;

B - Nie ma jasnych i absolutnych kryteriów określających, co jest dobre, a co złe. Dobro i zło zależy w znacznej mierze od okoliczności”. 
Stosunek maturzystów do ogólnych norm moralnych

\begin{tabular}{|c|c|c|c|c|c|c|c|c|c|c|c|c|}
\hline \multirow{2}{*}{$\begin{array}{c}\text { Kategorie } \\
\text { odpowiedzi }\end{array}$} & \multicolumn{2}{|c|}{ Szprotawa } & \multicolumn{2}{|c|}{ Puławy } & \multicolumn{2}{|c|}{ Kraśnik } & \multicolumn{2}{|c|}{ Dęblin } & \multicolumn{2}{|c|}{ Gdańsk } & \multicolumn{2}{|c|}{ Razem } \\
\hline & I & II & I & II & I & II & I & II & I & II & $\mathrm{I}$ & II \\
\hline $\begin{array}{c}\text { Twierdzenie } \\
\text { A } \\
\end{array}$ & 20,6 & 12,4 & 19,4 & 11,6 & 13,2 & 20,1 & 10,7 & 8,1 & 17,1 & 13,0 & 16,7 & 14,2 \\
\hline $\begin{array}{c}\text { Twierdzenie } \\
\text { B } \\
\end{array}$ & 62,4 & 73,0 & 62,8 & 68,4 & 63,4 & 56,1 & 76,7 & 78,4 & 64,1 & 73,6 & 64,6 & 67,6 \\
\hline Ani A ani B & 8,2 & 4,7 & 9,1 & 8,0 & 8,2 & 7,6 & 6,8 & 5,4 & 9,4 & 4,3 & 8,6 & 6,3 \\
\hline Brak zdania & 8,8 & 8,6 & 8,3 & 12,0 & 14,8 & 15,9 & 5,8 & 8,1 & 8,5 & 8,7 & 9,7 & 11,4 \\
\hline Brak danych & - & 1,3 & 0,4 & - & 0,4 & 0,4 & - & - & 0,9 & 0,5 & 0,4 & 0,5 \\
\hline Ogółem & 100,0 & 100,0 & 100,0 & 100,0 & 100,0 & 100,0 & 100,0 & 100,0 & 100,0 & 100,0 & 100,0 & 100,0 \\
\hline
\end{tabular}

W całej zbiorowości maturzystów w 2009 r. 14,2\% badanych skłaniało się ku twierdzeniu, że istnieją jasne i niepodważalne zasady, pozwalające odróżnić dobro od zła, stosujące się do każdego i w każdej sytuacji (od 8,1\% do 20,1\% w poszczególnych miastach). Ponad dwie trzecie badanych optowało za twierdzeniem, że nie istnieją ustalone raz na zawsze zasady pozwalające odróżnić dobro od zła (od 56,1\% do 78,4\%). Mniej niż co dziesiąty badany nie zgadzał się ani z pierwszym ani z drugim twierdzeniem i nieco częściej niż co dziesiąty ankietowany nie miał zdania na ten temat. Zdecydowana większość młodzieży kończącej szkoły ponadgimnazjalne jest przekonana o względności norm moralnych i to niezależnie od wielkości miasta, w którym młodzież uczęszcza do szkół. Najbardziej skłaniają się ku relatywizmowi moralnemu maturzyści z Liceum Lotniczego w Dęblinie, Gdańsku i Szprotawie. Uzyskane wyniki empiryczne wskazują na występowanie między tymi zmiennymi zależności statystycznej o bardzo słabej sile ( $\mathrm{p}=0.006 ; \mathrm{C}=0.182)$.

Kobiety podobnie często jak mężczyźni opowiadają się za twierdzeniem A $(13,8 \%$ wobec $14,7 \%)$ i nieco częściej za twierdzeniem B (70,6\% wobec 64,7\%); 5,3\% badanych kobiet i 7,2\% badanych mężczyzn nie zgadza się z obydwoma twierdzeniami (brak zdania lub brak odpowiedzi odpowiednio: 10,3\%, $13,5 \%)$. Pomiędzy płcią badanych a stosunkiem do kryteriów dobra i zła moralnego nie zachodzi zależność statystyczna $(\mathrm{p}=0.188)$. Opinie młodzieży uczęszczającej do liceów i techników są nieco odmienne. Młodzież z liceum ogólnokształcącego w 12,3\% opowiadała się za normami uniwersalnymi, w 71,7\% - za normami zrelatywizowanymi, w 5,6\% - nie wybierała ani twierdzenia A ani twierdzenia B i w 10,4\% - wyrażała opinie niezdecydowane lub nie udzieliła odpowiedzi (młodzież z techników odpowiednio: 17,3\%, 61,3\%, 7,2\%, 14,2\%). W ogólnych orientacjach moralnych występują pewne różnice ze względu na typ szkoły, młodzież z liceów nieco wyraźniej niż młodzież z techników skłania się ku relatywizmowi moralnemu. Potwierdza tę zależność test istotności statystycznej o bardzo słabej sile $(\mathrm{p}=0.001, \mathrm{C}=0.133)$. 
Młodzież mieszkająca na wsi w $15,0 \%$ opowiada się za jasnymi i trwałymi kryteriami moralnymi, w 66,0\% - nie przyjmuje tych kryteriów, w 5,7\% - zajmuje stanowisko pośrednie i w 13,3\% - prezentuje postawę niezdecydowana lub nie udziela odpowiedzi. Odpowiednie dane empiryczne dla młodzieży z miast do 20 tys. mieszkańców kształtują się następująco: 15,4\%, 68,6\%, 3,8\%, 12,1\%; dla miast od 20 do 100 tys. mieszkańców - 14,3\%, 67,4\%, 8,9\%, 9,4\%; dla miast powyżej 100 tys. mieszkańców - 10,7\%, 71,4\%, 6,6\%, 11,2\%. Zarówno z danych procentowych, jak i z testu chi-kwadrat wynika brak zależności statystycznej pomiędzy zmiennymi ( $\mathrm{p}=0.567)$, chociaż młodzież z wielkich miast wykazuje nieco wyższą aprobatę relatywizmu i sytuacjonizmu moralnego.

Postawy maturzystów wobec religii różnicują w sposób wyraźny ich stosunek do kryteriów dobra i zła moralnego. Wśród głęboko wierzących 29,5\% badanych wybiera twierdzenie A, 52,3\% - twierdzenie B, 8,0\% - ani jedno ani drugie twierdzenie, $10,2 \%$ - niezdecydowani lub nie udzielający odpowiedzi. Odpowiednie wskaźniki dla wierzących kształtują się następująco: $14,6 \%$, $65,2 \%, 6,6 \%, 13,6 \%$; dla niezdecydowanych w sprawach wiary $-14,9 \%, 71,8 \%$, $3,6 \%, 9,7 \%$; dla obojętnych religijnie - 5,5\%, 78,0\%, 4,6\%, 11,9\%; dla niewierzących $-1,9 \%, 79,2 \%, 15,1 \%, 3,8 \%$. W miarę przechodzenia od osób głęboko wierzących do osób niewierzących zmniejszają się wskaźniki przekonanych o trwałych kryteriach dobra i zła oraz wzrastają wskaźniki relatywizujących te kryteria. Obydwie zmienne łączą się w stopniu statystycznie istotnym o słabej sile $(\mathrm{p}=0.000, \mathrm{C}=0.227)$.

W latach 1994-2009 nastapiły tylko nieznaczne przesunięcia w poglądach badanych maturzystów na temat funkcjonowania norm moralnych w życiu codziennym. Wprawdzie ubyło nieco tych, którzy akceptują uniwersalizm norm moralnych (różnica 2,5\%) i przybyło tych, którzy skłaniają się ku relatywizmowi moralnemu (różnica 3,0\%), ale są to przesunięcia bardzo nieznaczne. Biorąc pod uwagę twierdzenie A można powiedzieć, że wskaźnik akceptujących normy moralne zmniejszył się w Szprotawie o 8,2\%, w Puławach o 7,8\%, w Dęblinie o 2,6\%, w Gdańsku o 4,1\% oraz zwiększył się w Kraśniku o 6,9\%.

Młodzież maturalna w 2009 r. - w porównaniu z pokoleniem ludzi dorosłych - w znacznie mniejszym stopniu skłania się ku twierdzeniu, że istnieją jasne i wyraźne kryteria odróżniania dobra i zła moralnego, bardziej relatywizuje swoje odpowiedzi, odchodzi od „dogmatycznego” punktu widzenia w kwestiach moralnych. Zarówno dzisiaj jak i 15 lat wcześniej, jedynie mniejszość maturzystów opowiada się za kodeksem etycznym wytyczającym linie demarkacyjne miedzy dobrem i złem. Rozmiary upowszechniającego się relatywizmu moralnego są trudne do precyzyjnego określenia. W latach 1994-2009 nastapiło tylko nieznaczne odejście od postaw wskazujących na aprobatę etyki bezwzględnych zasad. Nie można więc mówić - w świetle analizowanego wskaźnika - o jakimś kierunkowym trendzie rozwojowym orientacji moralnych, raczej o utrwaleniu się na niskim poziomie przekonania, że istnieją wyraźnie określone zasady wy- 
znaczające dobro i zło, obowiązujące wszystkich niezależnie od okoliczności. Rzeczywista moralność, tj. istniejąca w strukturach społecznych, wyzbywa się powoli swoich uniwersalistycznych roszczeń. Prawdopodobnie w tych okolicznościach zacierają się obiektywne granice między dobrem i złem, a kryteria moralne nabierają cech ,elastycznych" i ,relatywnych" i to - z pewnymi różnicami - we wszystkich analizowanych kategoriach demograficznych i społecznych, a nawet do pewnego stopnia i religijnych (np. u osób głęboko wierzących).

\section{Postawy zasadnicze i celowościowe}

Ważnym wskaźnikiem ogólnych orientacji moralnych w społeczeństwie są postawy zasadnicze i celowościowe, zwane inaczej postawami pryncypialnymi i instrumentalnymi. Chodzi tu o bardzo ważne pytania natury egzystencjalnej: czy można tak żyć, aby od żadnej zasady moralnej uznawanej przez siebie nie odstąpić, czy też wolno przyjąć taką postawę, według której - zależnie od sytuacji czy okoliczności - należy być gotowym do odstapienia od uznawanych przez siebie zasad? Inaczej mówiąc, czy należy normom moralnym przypisywać bezwarunkowe czy warunkowe obowiązywanie. Koncepcję postaw zasadniczych i celowościowych wprowadził do polskiej socjologii moralności Adam Podgórecki. Postawę zasadniczą można definiować ,,jako bezpośrednią, spontaniczną akceptację lub negację pewnej reguły, odnoszącej się do wyobrażonego lub rzeczywistego zachowania". <Postawq celowościowq〉 jest, zgodnie z proponowanq definicja, taka postawa, w przypadku której akceptacja lub negacja wyobrażonego lub rzeczywistego zachowania zależy od specyficznego rozważenia kalkulacji różnych możliwych wariantów zachowania oraz od oceny ich skutków [Podgórecki: 1998: 51-52].

W postawie zasadniczej akceptuje się normy ze względu na zasady, w postawie celowościowej - ze względu na skutki. Podgórecki, który podjął próbę operacjonalizacji rozróżnień wprowadzonych do nauk prawnych przez Leona Petrażyckiego, rozumiał postawę zasadniczą i celowościową nie tyle jako coś, co charakteryzuje zawartość (treść) tych postaw, ile raczej jako szczególny rodzaj struktury osobowości [Podgórecki, Kwaśniewski, Łoś-Bobińska, Kurczewski: 1968: 27]. W ustabilizowanych systemach politycznych przewagę maja postawy zasadnicze, jako odbijające istniejący porządek w strukturach społecznych. W systemach podlegających zmianom przeważać będzie postawa celowościowa jako bardziej adekwatna do nieustannie przeobrażających się okoliczności. Jednocześnie można zauważyć, że przyttaczająa przewaga postaw celowościowych może być również sytuacja dysfunkcjonalna, pozbawiajacq system autonomicznej sity społecznej, niezbędnej dla zrealizowania podstawowych funkcji tegoż systemu [Podgórecki: 1998: 53]. 
Zarówno postawy zasadnicze, jak i celowościowe mogą występować w pojedynczych sektorach osobowości, mogą tworzyć określone konfiguracje, a także utrwalać się w formie całościowo uogólnionej osobowości instrumentalnej lub zasadniczej. Postawy zasadnicze są związane z przekonaniami charakterystycznymi dla społeczeństw stabilnych (wysoka wrażliwość moralna, wysoki poziom internalizacji norm, przywiązanie emocjonalne), postawy celowościowe są natury pragmatycznej, związane ze zmiennymi wzorami zachowań i w sposób luźny powiązane $\mathrm{z}$ tłem emocjonalnym. $\mathrm{W}$ jedną i drugą kategorię postaw moga być ,wdrukowane” zarówno treści społecznie i moralnie pozytywne jak i negatywne. Przyttaczajaca dominacja postaw zasadniczych może być symptomem stagnacji ustroju społecznego, może być zatem patologicznym stanem, który utrudnia lub niweczy tendencje ustrojowe danego systemu, a znów przyttaczajaca dominacja postaw celowościowych może być stanem patologicznym, gdyż pozbawia system bazy, rezerwy samoistnej sity spotecznej, nieodzownej do realizacji jego podstawowych funkcji [Podgórecki: 1998: 53]. Podgórecki i jego zespół przyjmowali jako hipotezę roboczą, że w społeczeństwie polskim w latach sześćdziesiątych następowało przesunięcie $\mathrm{w}$ kierunku dominacji postaw celowościowych [Podgórecki, Kwaśniewski, Łoś-Bobińska, Kurczewski: 1968: 4].

Socjologom koncepcja „zasadniczości - celowości” służy do opisu i charakterystyki działań nakierowanych na ,zasady” lub ,sytuacje”. Zarówno postawy zasadnicze jak i celowościowe mogą być związane z dobrem lub złem moralnym, dotyczyć słusznej sprawy lub wprowadzić do zaangażowania się w sprawę uznaną w społeczeństwie za negatywną i niesłuszną. Stąd wartość moralna zajmowanych postaw będzie zależeć nie tyle od tego, czy człowiek jest zdolny do wierności zasadom lub sytuacjom, ale od tego, jakie są to sytuacje i zasady. $\mathrm{Z}$ punktu widzenia socjologii obydwa typy postaw mają charakter neutralny, to znaczy same w sobie nie są ani dobre ani złe w sensie etycznym. Koncepcja postaw zasadniczych i celowościowych ma więc przede wszystkim wymiar empiryczny i jest narzędziem stosowanym do opisu zmian zachodzących w różnych grupach społecznych i w całym społeczeństwie, w różnych okresach czasu.

W lutym 2009 roku - według sondażu CBOS - odpowiedzi respondentów na temat, jak dalece postępowanie ludzi powinno być podporządkowane pewnym zasadom moralnym, układały się następująco: należy mieć wyraźne zasady moralne i nigdy od nich nie odstępować - 31\%; należy mieć wyraźne zasady moralne, ale w pewnych sytuacjach można od nich odstąpić, byleby to były sytuacje wyjątkowe - 39\%; należy mieć pewne zasady moralne, ale nie ma w tym nic złego, kiedy się od nich odstępuje w związku z wymaganiami różnych sytuacji życiowych - 16\%; nie należy wiązać swojego postępowania określonymi z góry zasadami moralnymi, ale powinno się w zależności od sytuacji znajdować właściwe sposoby postępowania i zachowania - 9\%; trudno powiedzieć - 5\%. W latach 2005-2009 nie uległy zmianie wskaźniki tych, którzy opowiadali się za koniecznością posiadania wyraźnych i bezwzględnych zasad moralnych, na- 
tomiast wzrósł o blisko 9\% wskaźnik tych, według których warto mieć jasne zasady, ale w wyjątkowych sytuacjach można od nich odstąpić (moralność sytuacyjna) oraz zmniejszył się o 5\% wskaźnik tych, którzy całkowicie odrzucają stałe zasady moralne [Boguszewski: 2009: 2].

Rzeczywiste postawy ludzi rzadko są jednoznacznie zasadnicze lub jednoznacznie celowościowe, często są przejawem kompromisu pomiędzy ,zasadniczością" i ,instrumentalnością". Pewne normy moralne traktujemy jako bezwarunkowe i niedopuszczające wyjątków, inne jako warunkowo obowiązujące, i jesteśmy gotowi od nich odstąpić, jeżeli odstępstwo ukazuje się z jakichś względów korzystne dla nas lub dla innych. Kompromisowość wyraża się w swoistym dookreśleniu norm moralnych stosownie do sytuacji, a także w uprawnionych wahaniach w zależności od sytuacji. Młodzieży maturalnej badanej w roku szkolnym 2008/2009 przedstawiono m. in. następujące pytanie: „,Ludzie różnią się między sobą w poglądach na to, jak dalece ich postępowanie powinno być podporządkowane pewnym ogólnym zasadom moralnym. Który z podanych poglądów zbliżony jest do Twojego zdania na ten temat?

A - należy mieć wyraźne zasady moralne i nigdy od nich nie odstępować

B - należy mieć wyraźne zasady moralne, ale w pewnych sytuacjach można od nich odstapić, byleby to były sytuacje wyjątkowe

$\mathrm{C}$ - należy mieć pewne zasady moralne, ale nie ma w tym nic złego, kiedy się od nich odstępuje w związku z wymaganiami różnych sytuacji życiowych

D - nie należy wiązać swego postępowania określonymi z góry zasadami moralnymi, ale powinno się w zależności od sytuacji znajdować właściwe sposoby postępowania i zachowania".

Tabela 4

Postawy zasadnicze i celowościowe młodzieży (dane w \%)

\begin{tabular}{|c|c|c|c|c|c|c|c|c|c|c|c|c|}
\hline \multirow{2}{*}{$\begin{array}{l}\text { Typy postaw } \\
\text { (w symbolach) }\end{array}$} & \multicolumn{2}{|c|}{ Szprotawa } & \multicolumn{2}{|c|}{ Puławy } & \multicolumn{2}{|c|}{ Kraśnik } & \multicolumn{2}{|c|}{ Dęblin } & \multicolumn{2}{|c|}{ Gdańsk } & \multicolumn{2}{|c|}{ Razem } \\
\hline & $\bar{I}$ & II & $\mathrm{I}$ & II & $\bar{I}$ & II & I & II & $\bar{I}$ & II & I & II \\
\hline 4 & 10 & & 17 & & & & - & & 24,8 & & & \\
\hline $\mathrm{E}$ & & & 29,8 & 4 & 32,9 & & 8 & & & & & \\
\hline 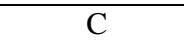 & & 20,6 & 24,4 & 16,0 & 20,6 & 16 & 1,4 & & 9,7 & 8 & 6 & 17,6 \\
\hline D & 2 & 9 & 28,5 & 7,2 & 26,7 & 5 & 16,5 & 2,7 & 19,2 & 10,1 & 24,6 & 7,9 \\
\hline Brak & & 6,9 & 3,7 & & 3,3 & 7 & 6,8 & & 2,1 & 9,1 & 3,4 & 7,2 \\
\hline Ogółem & 100,0 & 100,0 & 100,0 & 100,0 & 100,0 & 100,0 & 100,0 & 100,0 & 100,0 & 100,0 & 100,0 & 100,0 \\
\hline
\end{tabular}

Wśród maturzystów w 2009 r. w pięciu miastach Polski 25,3\% badanych było skłonnych traktować zasady moralne jako nakazy bezwzględnie obowiązujące niezależnie od sytuacji. Postawę umiarkowanie kompromisową (odstępstwo od uznawanych zasad tylko w wyjątkowych sytuacjach) prezentowało 42,0\% respondentów, postawę skrajnie kompromisową (odstępstwo od uznawanych 
zasad w związku z wymaganiami różnych sytuacji życiowych) - 17,6\% ankietowanych, a postawę celowościową (nie należy wiązać swojego życia stałymi zasadami moralnymi) - 7,9\% badanych (brak odpowiedzi - 7,2). Młodzież z Gdańska i Dęblina nieco mniej niż z pozostałych miast skłaniała się ku ,,zasadniczości” moralnej, bardziej zaś ku ,,praktycyzmowi” moralnemu. Pomiędzy typem ośrodka szkolnego a postawami zasadniczymi i celowościowymi nie występuje zależność statystyczna $(\mathrm{p}=0.076)$.

W latach 1994-2009 zaznaczyły się nieco zaskakujące zmiany. Wskaźnik postaw zasadniczych zwiększył się o 8,9\%, postaw umiarkowanie kompromisowych - o 9,1\%, natomiast zmniejszył się wskaźnik postaw skrajnie kompromisowych o $5,0 \%$ i celowościowych $-16,7 \%$. Wzrost postaw zasadniczych zaznaczył się szczególnie w trzech miastach: w Szprotawie (o 14,1\%), w Puławach (o 14,4\%) i w Kraśniku (o 13,0\%) oraz nieznacznie w Dęblinie (o 1,6\%) i zmniejszył się w Gdańsku (o 6,0\%). Przyrost postaw zasadniczych był większy wśród mężczyzn o (14,2\%) niż kobiet (o 3,7\%), wśród maturzystów z techników (o 11,5\%) większy niż z liceów ogólnokształcących (o 7,5\%); wśród młodzieży mieszkającej na wsi $(10,7 \%)$, w małych miastach (o 12,6\%) i w średnich miastach $(12,8 \%)$ większy niż w wielkich miastach (spadek o 3,9\%). W zbiorowości głęboko wierzących zasięg postaw zasadniczych zwiększył się o 7,8\%, wśród wierzących o 10,4\%, wśród niezdecydowanych w sprawach wiary o 11,7\%, wśród obojętnych religijnie o 9,0\% i wśród niewierzących o 5,7\%.

Porównanie wyników z tych sondaży pozwala na wyciagnięcie wniosku, że w latach 1994-2009 nastąpiło lekkie przesunięcie od postaw aprobujących etykę skrajnie sytuacyjną i skrajnie kompromisową, do postaw aprobujących postawy umiarkowanie kompromisowe i postawy zasadnicze. Wzrost postaw zasadniczych był relatywnie wyższy wśród maturzystów z małych i średnich miast (z wyjątkiem Dęblina) mężczyzn, młodzieży mieszkającej w małych i średnich miastach oraz wśród młodzieży wierzącej i niezdecydowanej w sprawach wiary. Tylko w Gdańsku i wśród młodzieży pochodzącej z wielkich miast nastąpiło przesunięcie w stronę dezakceptacji stałych zasad moralnych.

Jeżeli nawet - jak wykazały analizy empiryczne - zwiększyła się nieco obecność postaw zasadniczych w świadomości maturzystów, to bynajmniej nie musi to oznaczać postępującej ,uniwersalizacji” w świadomości w zakresie ogólnych orientacji moralnych w społeczeństwie szybkiej zmiany. Co prawda zaciera się ,widoczność" społeczna obowiązujących bez wyjątku norm, a nowe wyłaniają się z pewnym opóźnieniem, to nie musi to oznaczać w tym samym tempie przyrostu postaw zrelatywizowanych. Oprócz procesów rozpadu ładu aksjologicznego w wymiarach społecznych, dokonuje się coś, co można nazwać autonomizacją lub indywidualizacją moralności. Jednostka we własnym zakresie konstruuje swój świat wartości i norm moralnych, który dla niej jest obowiązujący i który stara się ona respektować w życiu codziennym. Stan i dynamikę tego procesu ,upodmiotowienia” moralności trudno jest w świetle zebranych 
danych empirycznych dokładnie ustalić, ale zachodzi on niewątpliwie w środowiskach młodzieżowych. Można by go opisać krótko: „w społeczeństwie ludzie odchodzą od stałych i niezmiennych zasad, ale ja osobiście mam swoje zasady i według nich postępuje".

Procesy autonomizacji moralności, w ramach których jednostki same decydują o kształtach swojej moralności, nie muszą oznaczać zahamowania rozpadu obiektywnego ładu moralnego w wymiarach społecznych, mogą się one łączyć także z tendencjami permisywistycznymi czy relatywistycznymi. „Pożegnanie z uniwersalizmem" oznacza, że w ogólnych orientacjach moralnych wpisany jest nie tyle wymiar powinności, ile raczej dowolna inicjatywa podmiotu. Jest to odchodzenie od etyki obiektywnej do subiektywnej, od uniwersalnej do sytuacyjnej czy relatywistycznej.

\section{Instancje pomocowe w rozwiązywaniu konfliktów moralnych}

Współcześnie podkreśla się szczególnie kreatywny charakter sumienia w określaniu tego, co dobre i złe. Jego aktów nie określa się już mianem sądów, ale decyzji. W konsekwencji tylko poprzez autonomiczne podejmowanie tych decyzji człowiek może osiagnąć moralną dojrzałość. Nie brakuje zwolenników poglądu, że przeszkodą dla tego procesu dojrzewania jest zbyt kategoryczne stanowisko Magisterium Kościoła katolickiego w kwestiach moralnych, wywołujące u wiernych niepotrzebne konflikty sumienia. W rozwiązywaniu konfliktów moralnych ludzie współcześni odwołują się do różnych instancji wspomagających i doradczych lub uznają, że sami powinni rozstrzygać wszelkie dylematy i wątpliwości. Wśród instytucji wspomagających coraz rzadziej pojawia się Bóg i instytucje kościelne. Człowiek wskazówek dla swojego życia poszukuje raczej $w$ samym sobie $i w$ sytuacjach życiowych, anizeli $w$ Bogu i objawionym przez Niego stowie, $w$ podanych przez Niego przykazaniach, a także $w$ instytucjach religijnych - twierdzi socjolog lubelski [Dyczewski: 2007: 23]. We współczesnym świecie upowszechnia się przekonanie o konieczności bycia autorytetem, tj. postępującym według własnych przekonań, w zgodzie z własnym sumieniem.

W warunkach strukturalnej indywidualizacji upowszechnia się przekonanie o sumieniu jako o ostatecznej instancji decydującej o tym, co człowiek hic et nunc powinien czynić, wybierając spośród poszerzającej się oferty wartości i norm, bez specjalnej troski o zgodność z instytucjonalnymi nakazami Kościoła. Miejsce obiektywnej prawdy zajmuje subiektywna autentyczność, w której łatwo usprawiedliwić lub potępić niemal wszystko, zwłaszcza w warunkach braku jednoczących wartości oraz niepodważalnych autorytetów, gwarantujących trwałość i powszechność zasad moralnych. Współczesny Polak uświadamia sobie w pełniejszy sposób prawo do osobistej realizacji wartości i norm, wraz z poczuciem niezależności, nie zawsze jednak także z poczuciem odpowiedzial- 
ności za siebie samego i innych. Taka tendencja oznacza zaakcentowanie subiektywnej normy moralności, niedocenianie obiektywnych norm prawa moralnego (naturalnego i objawionego) i ewoluowanie w stronę dowolności i relatywizmu (pewna odmiana sekularyzacji). Z pewnością utrwala się poczucie autonomii moralnej.

Sumienie oddzielone od religii (sumienie w ,świeckim przebraniu”) może być łatwo zdegradowane do rangi osobistych upodobań, wiązać się z indywidualizmem, utylitaryzmem lub ekspresjonizmem. Sens wyborów moralnych jest niestabilny, płynny, nieokreślony, zmienny. Jeśli tak jest, to jeszcze raz widać wyraźnie, że nie da się abstrakcyjnie ustalić praw moralnych raz na zawsze, że refleksja moralna musi uwzględniać konkretne sytuacje, musi być namystem wychodzacym od indywidualnego przypadku. Nie jest to powrót do dawnej kazuistyki, bo nie chodzi o formułowanie szczegółowych reguł zachowania, lecz powrót do bardziej skomplikowanego widzenia świata i motywacji ludzkich, które wprawdzie pozostawia jednostce decyzje, co zrobić $w$ konkretnej sytuacji, ale jednocześnie czyni tę decyzję niestychanie trudna, pokazujac, że nic nie gwarantuje końcowego sukcesu moralnego [Krasnodębski: 2006: 286].

Postawione w kwestionariuszu ankiety pytanie: „Czym kierujesz się w rozwiązywaniu problemów moralnych?” dotyczy wprost autorytetów moralnych, pośrednio może być interpretowane jako poszukiwanie instancji pomagających w rozstrzyganiu konfliktów między różnymi wartościami, normami czy wzorami zachowań, ale też jako pytanie dotyczące relacji religii i moralności. O wyborze wartości i norm w świadomości młodych Polaków częściej decydują czynniki subiektywne niż obiektywne. W rozwiązywaniu konfliktów i dylematów moralnych wzrasta rola indywidualnego osądu, utożsamianego często z sumieniem. Respondenci mieli do wyboru sześć różnych instytucji pomocnych w rozwiązywaniu konfliktów moralnych (wybory wielokrotne). Mogli też wskazać na inne instancje lub osoby spoza przedstawionej im do oceny listy lub powstrzymać się od dokonania jednoznacznego wyboru. Być może dokonywane wybory instancji moralnych przedstawiałyby się inaczej, gdyby alternatywą dla sumienia było prawo Boże, Dekalog, zasady moralne katolicyzmu, a nie tylko nauczanie Kościoła czy rady spowiedników. Niezależnie od tego należy podkreślić, że uzyskiwane odpowiedzi mogą mieć w dużej mierze charakter deklaratywny, nie pokrywający się do końca z wyborami dokonywanymi w życiu codziennym. Uderza też niski wskaźnik tych, którzy nie doświadczają konfliktów moralnych, zdecydowana większość takie konflikty przeżywa i poszukuje odpowiednich instancji wspomagających w ich rozwiązywaniu.

W całej zbiorowości maturzystów 83,5\% badanych kieruje się w rozwiązywaniu problemów i konfliktów moralnych - według własnych deklaracji - własnym sumieniem. Z innych instancji wspomagających lub ,znaczących innych”, do których odwołują się młodzi w znacznie węższym zakresie, wyżej ceni się rady przyjaciół - 30,3\% i rady rodziny $(27,5 \%)$ niż nakazy Kościoła $(9,4 \%)$, 
ustalone ogólnie sposoby postępowania (8,7\%), rady księży (4,9\%); inne odpowiedzi $-1,3 \%$, nie doświadcza konfliktów moralnych $-2,1 \%$, trudno powiedzieć $-4,9 \%$, brak odpowiedzi $-0,1 \%$. Opinie badanej młodzieży uczącej się w różnych miastach są dość zbieżne z pewnymi trudnymi do wytłumaczenia różnicami. Młodzież z Dęblina i Gdańska nieco częściej podkreśla rolę sumienia, młodzież z Kraśnika częściej akcentuje rolę Kościoła i księży, młodzież z Gdańska wyjątkowo wysoko ceni rady przyjaciół. Ogólnie jednak ani rodzina, która przekazuje pewien określony system wartości i norm, ani instancje wychowania bezpośredniego i pośredniego, nie są tak znaczące w rozwiązywaniu dylematów i konfliktów moralnych, jak własne sumienie. Test chi-kwadrat wskazuje na zależność statystyczną o bardzo słabej sile $(\mathrm{p}=0.005, \mathrm{C}=0.122)$.

Tabela 5

Czynniki ważne w rozwiązywaniu problemów moralnych (dane w \%)

\begin{tabular}{|c|c|c|c|c|c|c|c|c|c|c|c|c|}
\hline \multirow{2}{*}{$\begin{array}{c}\text { Kategorie } \\
\text { odpowiedzi }\end{array}$} & \multicolumn{2}{|c|}{ Szprotawa } & \multicolumn{2}{|c|}{ Puławy } & \multicolumn{2}{|c|}{ Kraśnik } & \multicolumn{2}{|c|}{ Dęblin } & \multicolumn{2}{|c|}{ Gdańsk } & \multicolumn{2}{|c|}{ Razem } \\
\hline & I & II & I & II & I & II & $\mathrm{I}$ & II & I & II & I & II \\
\hline $\begin{array}{c}\text { Nauczanie } \\
\text { Kościoła }\end{array}$ & 3,6 & 4,7 & 7,0 & 28,0 & 5,8 & 14,0 & 3,9 & 5,4 & 11,5 & 9,1 & 6,8 & 9,4 \\
\hline Rady rodziny & 0,3 & 28,3 & 10,7 & 24,4 & 3,2 & 30,3 & 9,7 & 16,2 & 15,8 & 28,8 & 12,3 & 27,5 \\
\hline $\begin{array}{l}\text { Wła } \\
\text { sum }\end{array}$ &, 9 & 81,5 & 85,5 & 78,8 & 82,3 & 82,6 & 86,4 & 91,9 & 89,7 & 90,9 & 84,9 & 83,5 \\
\hline $\begin{array}{r}\text { Ogóli } \\
\text { sposol } \\
\text { posteppov }\end{array}$ & 4,1 & 8,2 & 2,9 & 8,0 & 2,9 & 8,7 & 11,7 & 10,8 & 11,5 & 9,6 & 6,0 & 8,7 \\
\hline Rady 1 & 2,6 & 3,0 & 2,1 & 4,8 & 1,6 & 6,8 & 1,0 & 5,4 & 5,1 & 4,8 & 2,7 & 4,9 \\
\hline $\begin{array}{r}\mathrm{Rac} \\
\text { przyja }\end{array}$ & 9,3 & 32,2 & 18,2 & 25,2 & 15,6 & 26,9 & 16,5 & 18,9 & 18,4 & 40,9 & 15,7 & 30,3 \\
\hline Inne & 2,6 & 1,3 & 5,4 & 2,0 & 1,2 & - & 1,9 & - & 3,4 & 2,4 & 3,1 & 1,3 \\
\hline $\begin{array}{r}\mathrm{B} \\
\text { konfl }\end{array}$ & 3,1 & 9 & 0,4 & 1,6 & 2,5 & 1,5 & 2,9 & - & 0,9 & 1,9 & 1,8 & 2,1 \\
\hline $\begin{array}{r}\text { Tru } \\
\text { powie }\end{array}$ & 7,7 &, 0 & 5,8 & 8,0 & 9,5 & 4,5 & 3,9 & - & 1,7 & 1,4 & 5,9 & 4,9 \\
\hline Brak danych & - & - & 0,4 & - & - & 0,4 & - & - & 0,4 & - & 0,2 & 0,1 \\
\hline
\end{tabular}

W latach 1994-2009 nie nastapiły istotne zmiany w uznawanych instancjach wspomagających maturzystów w rozwiązywaniu konfliktów moralnych, z dwoma wyjątkami. Wyraźnie wzrosła rola rodziny (o 15,2\%) i przyjaciół (o 14,6\%). Nieznacznie zwiększyła się rola Kościoła (o 2,6\%), ogólnych sposobów postępowania (o 2,7\%), rad księży (o 2,2\%) i zmniejszyła się rola własnego sumienia $(0$ 1,4\%). Tendencje te zaznaczyły się w zbliżony sposób we wszystkich pięciu miastach. W latach 1994-2009 zmniejszyła się wśród mężczyzn rola sumienia o 4,3\%, wśród kobiet wzrosła o 1,3\%, kryteriów religijnych zmniejszyła się wśród mężczyzn o 0,2\% i zwiększyła się wśród kobiet o 2,0\%. Młodzież 
licealna w 2009 r. częściej o 2,2\% niż w 1994 r. akceptowała sumienie jako instancję priorytetową i o 3,8\% częściej kryteria religijne, wśród młodzieży z techników w pierwszej kwestii nastąpił spadek akceptacji o 7,0\% i wzrost w drugiej kwestii o 4,0\%. Rola sumienia zmniejszyła się o 3,1\% na wsi, o 2,0\% $\mathrm{w}$ małych miastach, o 3,2\% w wielkich miastach i nieco wzrosła w średnich miastach (o 2,5\%). Kryteria religijne zyskały na znaczeniu w środowiskach wiejskich (o 2,9\%), w małych miastach (o 5,5\%), w średnich miastach (o 12,8\%) i straciły na znaczeniu w wielkich miastach (o 4,0\%). Postawy wobec religii nie wiązały się ze zmianą roli sumienia w latach 1994-2009 (zmiany w granicach $2 \%$ ), o tyle kryteria religijne nieco wzrosły u głęboko wierzących o $7,7 \%$ i wierzących (o 6,0\%).

Zgromadzone dane empiryczne uprawomocniają - przynajmniej pośrednio - tezę amerykańskiego socjologa Petera L. Bergera o zmieniającej się lokalizacji moralnego osądu i o przesunięciu kognitywnym moralności. Podstawą sądów moralnych jest percepcja, co oznacza, że moralność ma z istoty charakter poznawczy. Sumienie ma nie tyle charakter imperatywny (,,rób to, lub tamtego nie rób"), lecz funkcje wskazująco-informacyjne, dające rozeznanie w różnych sytuacjach życiowych. Dokonująca się zmiana oznacza odchodzenie od normatywnych przykazań do poznawczych funkcji sumienia (tzw. efekt zmiany poznawczej) [Berger: 2007: 228-232]. W tym kontekście nie zwraca się uwagi na fakt, że sumienie jednostki, nie wspierane przez normy moralne oraz instytucje i sankcje, może być przyćmione, a jego decyzje mogą być nietrafne, czysto subiektywne.

\section{Uwagi końcowe}

Ogólnie sformułowane przykazania Dekalogu są uznawane teoretycznie w dalszym ciagu jako podstawa trwałości społeczeństwa, natomiast w kwestiach konkretnych, które nie mają takiej społecznej doniosłości, istnieje wolność indywidualnego wyboru. Zasięg społeczny tak określonego połowicznego permisywizmu jest trudny do określenia. Trwałe zasady moralności, zwłaszcza zaś o proweniencji religijnej, tracą $\mathrm{w}$ świadomości znacznej części młodzieży polskiej rangę drogowskazów w codziennych wyborach i decyzjach. Być może mamy tu do czynienia nie tyle $\mathrm{z}$ anomią moralną oznaczającą brak norm czy brak jasności w ich rozumieniu, lecz raczej z ambiwalentnym stosunkiem do tradycyjnych wartości i norm moralnych nauczanych przez Kościól. Jeżeli wartości i normy moralne stają się sprawą indywidualnego sumienia, można wówczas mówić o postępującym procesie prywatyzacji (indywidualizacji) moralności.

W każdym razie nie wydaje się, by młodzież pod koniec pierwszej dekady XXI w. w swoich ogólnych orientacjach moralnych bardziej skłaniała się ku relatywizmowi niż ta na początku lat dziewięćdziesiątych, nawet jeżeli zmieniło 
się nieco w tym okresie pojmowanie moralności. W świetle dwóch powtarzanych badań empirycznych trudno byłoby mówić o jakimś nowym kierunkowym trendzie rozwojowym orientacji moralnych. Zmniejszenie się zasięgu postaw celowościowych na rzecz postaw kompromisowych może być interpretowane jako przejaw wzrostu racjonalizacji w myśleniu i działaniach codziennych młodych Polaków, bądź jako przejaw wyraźniejszego konfliktu pomiędzy normami moralnymi nakazującymi uczciwość, przyzwoitość, solidarność i lojalność a normami pragmatycznej skuteczności, kariery i sukcesu. W odniesieniu do wartości i norm o charakterze ogólnym mamy nie tyle do czynienia z jakąś negacją dobra moralnego, ile raczej z chwiejną dezorientacją i ambiwalencją.

Badana młodzież maturalna charakteryzuje się dość daleko posunięta ostrożnością, a nawet niechęcią w akceptowaniu nakazów płynących z ,góry", zobowiązujących w sposób kategoryczny i obiektywny. Wielu młodych ludzi przyznaje, że nie ma wzorów osobowych, swoje przekonania moralne kształtuje niezależnie od instancji zewnętrznych, pojawiające się konflikty moralne rozwiązuje we własnym sumieniu. Ten kształt indywidualnego stylu życia według własnych opcji i wyborów charakteryzuje znaczne kręgi młodzieży kończącej szkoły ponadgimnazjalne. Można przypuszczać, że wzrasta krytycyzm i samoświadomość młodzieży wobec osób i grup pełniących funkcje autorytetów społecznych i moralnych. Jeżeli postmodernistyczne hasło: „,nie ma żadnych autorytetów” lub „każdy odpowiada za wszystko” przenieść z dziedziny sztuki do moralności, to znaczna część badanej młodzieży maturalnej hołduje już tym hasłom w praktyce życiowej.

Autonomizowanie się wyborów moralnych w środowiskach młodzieżowych, co wyraża się m. in. w krytycznym stosunku do tradycyjnych autorytetów, wynika z różnych przyczyn, częściowo także niezależnych od uczniów. Negatywne reakcje emocjonalne wobec autorytetów i kierowanie się wyłącznie własnym zdaniem w rozstrzyganiu konfliktów moralnych może być jednak zjawiskiem niebezpiecznym, prowadzącym do izolacji społecznej, jeżeli nie ma charakteru przejściowego - od moralności przymusu i jednostronnego autorytetu, do moralności współdziałania i wzajemnego szacunku. Z punktu widzenia wychowawczego ważne jest kształtowanie dojrzałego i prawego sumienia, wyrabianie zdolności obiektywnego osądu i tworzenie autentycznych więzi społecznych.

Niechęć wielu młodych ludzi do zinstytucjonalizowanych autorytetów nie musi oznaczać zakwestionowania w ogóle autorytetów w sprawach moralnych. Warto w tym kontekście przytoczyć wypowiedź Jana Pawła II: W każdej fazie zycia człowiek pragnie być afirmowany, pragnie znajdować miłość. W tej epoce pragnie tego w szczególny sposób - przy czym ta afirmacja nie może być akceptacja wszystkiego bez wyjatku. Młodzi wcale tego nie chca. Chcq także, aby ich poprawiać, chca, aby mówić im 〈tak>lub <nie>. Potrzebuja przewodników i to potrzebuja tych przewodników bardzo blisko. Jeżeli odwotuja się także do pew- 
nych autorytetów, to tylko o tyle, o ile te autorytety potwierdzaja się równocześnie jako ludzie bliscy, jako ci, którzy ida z młodzieża po wszystkich szlakach, po których ona postępuje [Przekroczyć próg nadziei: 1994: 106].

\section{Bibliografia:}

Beck Ulrich, 2006, Zacząt się wyścig cywilizacji, „Dziennik”, nr 211.

Berger L. Peter, 2007, Pytania o wiarę. Sceptyczna zachęta do chrześcijaństwa, Tł. Jerzy Łoziński, Instytut Wydawniczy Pax, Warszawa.

Bocheński Józef, 1995, Dzieła zebrane. Etyka, Wydawnictwo PHILED, Kraków.

Boguszewski Rafał, 2009, Moralność Polaków po dwudziestu latach przemian, Komunikat z badań CBOS-u BS/40, Warszawa.

Dyczewski Leon, 2007, Rodzina $i$ jej miejsce $w$ hierarchii wartości mtodego pokolenia Europejczyków. Wyniki Badań socjologicznych, [w:] Julia Gorbaniuk (red.), Sytuacja rodziny we wspótczesnym społeczeństwie - doświadczenia Europy Środkowo-Wschodniej, Wydawnictwo KUL, Lublin.

Gärtner Christel, 2003, Egotaktiker mit spontanen Solidaritätsverpflichtungen? Zur Wahrnehmung jugendlicher Engagementbereitschaft in der Jugendforschung, [w:] Solidarität institutionalisieren. Arenen, Aufgaben und Akteure christlicher Sozialethik, Beiträge aus dem ,,Institut für Christliche Sozialwissenschaften”, Karl Gabriel zum 60. Geburtstag. Hrsg. von HermannJosef Große Kracht. LIT Verlag, Münster.

Kiciński Krzysztof, 2008, Autonomia moralna - wartość epoki postautorytarnej (w świetle rozważań Stanisława Ossowskiego), [w:] J. Mariański, L. Smyczek (red.), Wartości, postawy $i$ więzi moralne $w$ zmieniajacym się społeczeństwie, Wydawnictwo WAM. Kraków.

Liberalny totalitaryzm, 2005, Rozmowa z Anną Pawełczyńską. Rozmawiał Wojciech Chmielewski, ,Nowe Państwo”, nr 1.

Mariański Janusz, 2009, Dylematy moralne młodzieży polskiej, [w:] D. Walczak-Duraj (red.), Wartości i postawy młodzieży polskiej, Wydawnictwo Uniwersytetu Łódzkiego, Łódź.

Pawełczyńska Anna, 2004, Głowy hydry. O przewrotności współczesnego zła, Wydawnictwo Test, Warszawa.

Podgórecki Adam, 1998, Socjologiczna teoria prawa, Tł. Łucja M. Kwaśniewska, Roland Smogór, Wydawnictwo INTERART-TAL, Warszawa.

Podgórecki Adam, Kwaśniewski Jerzy, Łoś-Bobińska Maria, Kurczewski Jacek, 1968, Poczucia prawne i moralne społeczeństwa polskiego, Wydawnictwo Radia i Telewizji, Warszawa.

Przekroczyć próg nadziei, 1994, Jan Paweł II odpowiada na pytania Vittoria Messoriego, Redakcja Wydawnictw KUL, Lublin. 
Styk Józef, 2008, Wpływ wartości na wzory zachowań społecznych młodzieży, [w:] F. W. Wawro (red.), Młodzież w kulturze życia w kontekstach społecznych, Wydawnictwo KUL, Lublin.

Szahaj Andrzej, 2008, Relatywizm i fundamentalizm oraz inne szkice z filozofii kultury i polityki, Wydawnictwo Naukowe UMK, Torun.

Szlendak Tomasz, 2000, Rodzina, [w:] W. Kwaśniewicz (red.), Encyklopedia socjologii, t. III, Oficyna Naukowa, Warszawa.

Świda-Ziemba Hanna, 2000, Obraz świata i bycia w świecie (z badań młodzieży licealnej), Instytut Stosowanych Nauk Społecznych UW, Warszawa.

Ziółkowski Marek, 2006, Zmiany systemu wartości, [w:] Jacek Wasilewski (red.), Wspótczesne społeczeństwo polskie. Dynamika zmian, Wydawnictwo Naukowe SCHOLAR, Warszawa.

\title{
MORAL AWARENESS OF HIGH SCHOOL SENIORS FROM 1994-2009
}

\begin{abstract}
Summary
The issue of continuity and change of morality has always preoccupied sociologists. Lived morality, which functions in various social environments, comprises a broad spectrum of specific problems. The present paper will focus on a few overriding issues, for example: the Decalogue as a foundation of morality, the attitudes toward basic norms and values, criteria of moral good and evil, and on agencies conducive to solving conflicts and moral dilemmas. Moral changes in Polish society are marked in significant ways by the clash of two ethical norms: Catholic morality and liberal morality (in its various manifestations). The present study is based on empirical data gathered in 1994 and 2009 within the same schools and classes in five cities (Szprotawa, Puławy, Kraśnik, Dęblin, Gdańsk). Repeated surveys allow monitoring the dynamics of changes and ongoing social processes.
\end{abstract}

Key words: moral awareness, high school seniors, decalogue, value, norms, catholic morality, liberal morality. 